DOI:10.18276/sip.2016.45/2-18

\title{
Iwona Foryś*
}

Małgorzata Tarczyńska-Łuniewska**

Uniwersytet Szczeciński

\section{STABILNOŚĆ WSKAŹNIKÓW STRUKTURY MAJĄTKU WYBRANYCH SPÓŁEK DEWELOPERSKICH NOTOWANYCH NA GIEŁDZIE PAPIERÓW WARTOŚCIOWYCH W WARSZAWIE W LATACH 2007-2013}

\begin{abstract}
Streszczenie
Kondycja rynku nieruchomości i podmiotów na nim działających jest ściśle związana z koniunkturą gospodarczą. Negatywne zjawiska na rynku nieruchomości potwierdzają także słabe wyniki spółek deweloperskich notowanych na Giełdzie Papierów Wartościowych w Warszawie.

W artykule przeprowadzono rozważania dotyczące kondycji spółek deweloperskich notowanych na GPW w latach 2007-2013 w kontekście struktury ich kapitałów. Celem badania jest ocena struktury kapitałów i jej stabilności w spółkach deweloperskich aktywnych na rynku mieszkaniowym w Polsce. Wykorzystano dane ekonomiczno-finansowe badanych spółek deweloperskich. Wyznaczono podstawowe wskaźniki ekonomiczno-finansowe struktury majątku, które posłużyły do oceny ich stabilności w latach koniunktury i dekoniunktury na rynku nieruchomości.
\end{abstract}

Słowa kluczowe: spółki deweloperskie, wskaźniki struktury majątku, stabilność struktury

* Adres e-mail: forys@wneiz.pl.

** Adres e-mail: maluni@poczta.fm. 


\section{Wstęp}

Spółki deweloperskie charakteryzują się odmienną od innych podmiotów gospodarczych strukturą aktywów i pasywów wynikającą z wysokiego zaangażowania kapitałów własnych i obcych w krótkoterminowe projekty inwestycyjne. Zwrot tych środków następuje w momencie sprzedaży efektów inwestycyjnych, która może się odbywać w trakcie trwania inwestycji lub po jej zakończeniu. Tryb sprzedaży zależy od koniunktury na rynku nieruchomości. W okresie hossy sprzedaż przyszłych efektów ma miejsce już na etapie projektu, podczas gdy w czasie dekoniunktury nawet kilka lat po zakończeniu budowy. Czy lata 2009-2013 dekoniunktury gospodarczej wpłynęły na strukturę majątku spółek deweloperskich zaangażowanych w budownictwo mieszkaniowe w porównaniu do okresu koniunktury (lata 2007-2009)?

Zasadniczym celem artykułu jest badanie stabilności w czasie struktury majątku wybranych spółek sektora deweloperskiego z wykorzystaniem wybranych narzędzi analizy finansowej. W szczególności zastosowano metody analizy wstępnej bilansu dla wybranych spółek wchodzących w skład sektora deweloperskiego na Giełdzie Papierów Wartościowych w Warszawie w latach 2007-2013.

\section{Przesłanki analizy finansowej sektora deweloperskiego}

Procesy zachodzące w gospodarce rynkowej mają charakter dynamiczny i ewolucyjny. Skutkuje to zmianami, jakie można obserwować zarówno w zakresie funkcjonowania gospodarki, jak i podmiotów wchodzących w jej skład. Zmianom ulega także struktura rynku przejawiająca się między innymi pojawianiem się nowych sektorów gospodarki (np. sektor deweloperski, energetyczny) czy wzrastającą liczbą przedsiębiorstw. Stan rynku również charakteryzuje się zamieniającym zaangażowaniem uczestników rynku w różnych sferach gospodarki, co można zauważyć na rynku nieruchomości. Rynek ten od kilku już lat jest analizowany przez jego uczestników z różnych punktów widzenia, jak chociażby pod kątem możliwości inwestycyjnych, kierunku rozwoju czy analizy cen nieruchomości itp. (Peiser, Frey, 2003; Peto 2011; Foryś 2003; Foryś, Tarczyński, 2011).

W ramach rynku nieruchomości coraz większą uwagę zajmuje sektor deweloperski, którego korzenie sięgają sektora budowlanego. Już samo wyodrębnienie się sektora deweloperskiego świadczy o ewolucyjnym charakterze rozwoju gospodarki. Potwierdzeniem jest również pojawienie się tego sektora na GPW. Skoro jednak 
przedsiębiorstwa deweloperskie prowadzą działalność gospodarczą tak jak inne podmioty rynku, to tak jak one nie pozostają obojętne na okresy koniunktury i dekoniunktury gospodarczej. Na kondycję spółek deweloperskich ma wpływ również sytuacja całego rynku nieruchomości, który po okresie hossy w latach 2005-2008 dalej wykazuje negatywne tendencje. Niekorzystny wpływ otoczenia gospodarczego na sektor deweloperski jest najczęściej widoczny w kondycji ekonomiczno-finansowej spółek deweloperskich i uzyskiwanych wynikach finansowych. Ocena przedsiębiorstwa od strony finansowej umożliwia identyfikację czynników wpływających na kondycję finansową przedsiębiorstwa.

Informacje odnoszące się do kondycji ekonomiczno-finansowej można uzyskać, wykorzystując odpowiednie narzędzia analizy finansowej. W literaturze przedmiotu analiza ta jest szeroko opisywana, a autorzy opracowań prowadzą merytoryczną dyskusję odnoszącą się do jej istoty, przeznaczenia, charakteru wykorzystania, ewolucji czy jej szczegółowości (Bednarski i in., 1996; Jachna, Sierpińska, 2009; Bień 1999; Wędzki 2009; Tyran 2005). Ponadto istnieje wiele opracowań praktycznych związanych z wykorzystaniem wybranych metod analizy finansowej do oceny podmiotów gospodarczych, rynku czy analizy i oceny sektorów funkcjonujących w ramach rynku (Batóg 1996, 1997; Bednarski i in., 1999; Zaleska, 2002; Łuniewska, Tarczyński, 2007; Skoczylas 2009; Dudycz, Skoczylas, 2014). Specyfika tej analizy powoduje, że zarówno analizę, jak i ocenę przedsiębiorstwa przeprowadza się etapami, w szczegółowy sposób odnosząc się do analizy wstępnej, wskaźnikowej czy merytorycznej (Waśniewski, 1997). Ponadto analizę można przeprowadzać w układzie statycznym i dynamicznym, przy czym w pierwszym przypadku odnosimy się do stanu, w drugim natomiast można zaobserwować zmiany w czasie analizowanego zjawiska. Analiza finansowa dopuszcza również prowadzenie analiz porównawczych w czasie, wielkości rzeczywistych z planowanymi oraz w przestrzeni (np. analizy sektorowe, między podmiotami itp.). Z reguły analizę finansową przeprowadza się dla pojedynczego podmiotu gospodarczego lub całego sektora.

Możliwa jest także kompleksowa analiza i ocena rynku przez pryzmat podmiotów go tworzących. Należy przy tym dodać, że analizy rynku mogą być prowadzone na różnym szczeblu agregacji i za pomocą różnych narzędzi analitycznych. Poznanie rynku lub jego części umożliwia nie tylko odniesienie się do stanu rynku, ale też określenie kierunku zmian. Ponadto analizy porównawcze przedsiębiorstw prowadzone w ramach wybranego sektora mogą wskazać lub uwypuklić występujące między podmiotami różnice i dysproporcje dla analizowanych problemów finansowych czy ekonomicznych. 
Z uwagi na specyfikę sektora deweloperskiego oraz fakt, że jest on dość młodym sektorem funkcjonującym w polskiej gospodarce, interesująca jest zwłaszcza kondycja tego sektora w okresie koniunktury i dekoniunktury gospodarczej. Złożony charakter analizy finansowej powoduje, że analizę sektora deweloperskiego również można prowadzić etapowo, na różnym poziomie szczegółowości i z różnej perspektywy. Dodatkowo dzięki takiemu działaniu możliwa jest identyfikacja podmiotów wiodących lub bardzo słabych w sektorze.

\section{Wstępna analiza bilansu w zakresie struktury kapitałowo-majątkowej}

Skutki decyzji i zdarzeń gospodarczych mających miejsce w przedsiębiorstwie w syntetyczny sposób są ujęte w jego sprawozdaniach finansowych. Ich analiza daje obraz sytuacji finansowej podmiotu gospodarczego, a zastosowanie odpowiednich narzędzi analitycznych umożliwia identyfikację relacji zachodzących między majątkiem a kapitałami.

We wstępnej analizie bilansu można wykorzystać analizę struktury (Jachna, Sierpińska, 2009):

- majątkowej - wykorzystując w tym celu wskaźniki struktury aktywów,

- kapitałowej - wykorzystując wskaźniki struktury pasywów,

- majątkowo-kapitałowej.

Analiza struktury majątkowej odnosi się do badania aktywów trwałych na podstawie bilansu przedsiębiorstwa. Analiza ta ma istotne znaczenie z punktu widzenia relacji występujących między aktywami i pasywami (w tym również poszczególnymi składowymi) oraz samej ich struktury. Warto przy tym spojrzeć na bilans i jego składowe z punktu widzenia typu prowadzonej przez podmiot działalności gospodarczej.

Struktura wielkości bilansowych jest ściśle związana z rodzajem prowadzonej działalności i powinna być znana zarówno osobom prowadzącym analizę, jak i osobom wykorzystującym taką informację. Wiedza ta pozwala na ocenę analizowanego podmiotu gospodarczego z punktu widzenia poprawności struktury wielkości bilansowych. Ponadto jest to ważna informacja odnosząca się do udziału składników majątkowych w wypracowaniu zysku. W ramach tego samego sektora i dla spółek prowadzących działalność gospodarczą tego samego typu wskaźniki struktury wielkości bilansowych nie powinny być zróżnicowane, a spółki powinny się charakteryzować podobnym poziomem tych wskaźników. 
W ramach prowadzonej analizy należy też zwrócić uwagę na rolę, jaką pełnią poszczególne składowe aktywów i pasywów dla danego typu działalności gospodarczej. W spółkach deweloperskich na przykład grunty stanowią część majątku obrotowego i jako zapasy są uwalniane w momencie rozpoczęcia inwestycji, na rzecz której zostały zakupione. W ocenie poprawności struktury wielkości bilansowych analityk powinien pamiętać o roli, jaką poszczególne składowe pełnią nie tylko w wypracowywaniu wyniku finansowego, ale również w zachowaniu stabilności funkcjonowania podmiotu gospodarczego. Przedsiębiorstwu łatwiej zaangażować w działalność gospodarczą środki wchodzące w skład majątku obrotowego niż trwałego, gdyż z reguły charakteryzują się one większą płynnością.

Analiza struktury majątkowej uwzględnia informacje dotyczące majątku trwałego (mało elastycznego) i obrotowego (płynnego). Proporcja wzajemnego udziału majątku trwałego i obrotowego względem aktywów ogółem jest różna w zależności od typu prowadzonej działalności gospodarczej. Przedsiębiorstwa dążą jednak do utrzymywania pewnego poziomu majątku trwałego, tak by możliwe było ich funkcjonowanie. Proporcjonalnie w strukturze aktywów majątek trwały powinien stanowić większą część. Ten typ majątku w głównej mierze w sposób bezpośredni przyczynia się do wypracowywania pozytywnego wyniku finansowego. Stąd w ramach analizy sytuacji majątkowej można zastosować między innymi wskaźniki obejmujące udział w aktywach ogółem rzeczowych składników majątku oraz majątku obrotowego. Ponadto można osobno badać strukturę aktywów trwałych i obrotowych.

Analiza struktury kapitałowej jest kolejnym bardzo ważnym etapem wstępnej analizy bilansu. Wskazuje na źródła finansowania aktywów, gdzie czynnikiem rozgraniczającym jest tak zwane kryterium własności kapitału. W ogólnym ujęciu kapitał przedsiębiorstwa dzieli się na: kapitał własny i kapitał obcy. Struktura kapitału w przedsiębiorstwie jest w głównej mierze uzależniona od prowadzonej polityki finansowej. Struktura kapitałowa wynikająca z pasywów bilansu daje obraz podstawy finansowej, na której oparta jest działalność przedsiębiorstwa (Waśniewski, 1997; Wędzki, 2009). Niewłaściwa struktura pasywów i zbyt duży udział kapitałów obcych może wpływać na zagrożenie płynności finansowej przedsiębiorstwa, w tym trudności płatnicze czy niewypłacalność. Jeśli stan taki utrzymuje się przez dłuższy czas, może to prowadzić także do upadłości przedsiębiorstwa.

W ramach analizy sytuacji kapitałowej można zastosować następujące wskaźniki:

- udział kapitałów własnych w pasywach ogółem,

- udział kapitałów obcych w pasywach ogółem,

- udział kapitału własnego względem kapitału obcego. 
W ramach analizy struktury kapitałów możliwe jest również badanie udziału poszczególnych składowych pasywów własnych i obcych. Analiza taka pozwala na poznanie struktury kapitałowej na wyższym szczeblu szczegółowości. Wskaźniki struktury kapitałowej wyrażone są w procentach.

Analiza struktury kapitałowo-majątkowej stanowi też istotny element w ocenie podmiotu gospodarczego. Umożliwia poznanie powiązań występujących między poszczególnymi składowymi aktywów i pasywów przedsiębiorstwa. Punktem wyjścia jest ustalenie udziału kapitału własnego w finansowaniu majątku przedsiębiorstwa. W przedsiębiorstwie powinna zachodzić „złota zasada bilansowa”, która oznacza, że majątek trwały jest w pełni pokryty kapitałem własnym. Taka sama relacja powinna zachodzić w przypadku kapitału krótkoterminowego i majątku obrotowego.

\section{Badanie struktury kapitału wybranych spółek deweloperskich notowanych na GPW}

W badaniu wykorzystano dane ekonomiczno-finansowe spółek deweloperskich notowanych na GPW. Natomiast wybór spółek wynikał z zakresu danych koniecznych do analizy w latach 2007-2013. Na koniec 2013 roku spółki deweloperskie na GPW reprezentowało 35 podmiotów, jednak nie dla wszystkich z nich możliwe było uzyskanie wyczerpujących informacji finansowych, które pozwoliłyby na szerszą analizę. Wyznaczone wskaźniki ekonomiczno-finansowe stanowiły zmienne użyte do oceny stabilności struktury kapitału tych spółek zarówno w latach hossy, jak i bessy na rynku nieruchomości. Uwzględniono spółki, których aktywność deweloperska koncentrowała się na rynku krajowym oraz przede wszystkim na projektach mieszkaniowych. Dodatkowo uwzględniono tylko te spółki, które prowadziły działalność i były notowane na GPW w latach 2007-2013. Ostatecznie analizie poddano 14 spółek deweloperskich.

Biorąc pod uwagę przychody netto osiągnięte w 2013 roku ze sprzedaży produktów, towarów i materiałów, można wybrane 14 spółek podzielić na trzy grupy: spółki duże, w których wskazane przychody netto przekroczyły $100 \mathrm{mln}$ zł, spółki średnie o przychodach poniżej $100 \mathrm{mln}$ zł, ale powyżej $10 \mathrm{mln}$ zł, oraz spółki małe o przychodach ze sprzedaży netto poniżej $10 \mathrm{mln}$ zł. W pierwszej grupie znalazły się: DOM_DEVEL, JW_CONST, ECHO_INV, LCCORP oraz TRITON. Do drugiej grupy zaliczono spółki: POLNORD, WIKANA, ED_INVEST, GTC, BBI_DEVEL. Pozostałe spółki (ALTA, ALTASET, KCI, CELPRODE) znalazły się w grupie trzeciej.

Dalej skoncentrowano się przede wszystkim na badaniu kapitałów wspomnianych spółek z uwagi na specyfikę działalności tego sektora podmiotów gospodarczych, 
których wyniki finansowe zależą od zakres prowadzonych inwestycji, posiadanych gruntów pod inwestycje czy też sposobu ich finansowania. Stąd w pierwszym kroku analizy dla badanych lat wyznaczono dwa wskaźniki pokrycia: majątku trwałego kapitałem własnym oraz majątku obrotowego kapitałem krótkoterminowym (tabela 1).

Tabela 1. Wskaźniki pokrycia majątku trwałego kapitałem własnym wybranych spółek deweloperskich notowanych na GPW

\begin{tabular}{|l|c|c|c|c|c|c|c|}
\hline \multirow{2}{*}{ Spółka } & \multicolumn{7}{|c|}{ Majątek długookresowy/kapitału długookresowego ( 1$)$} \\
\cline { 2 - 9 } & $\mathbf{2 0 0 7}$ & $\mathbf{2 0 0 8}$ & $\mathbf{2 0 0 9}$ & $\mathbf{2 0 1 0}$ & $\mathbf{2 0 1 1}$ & $\mathbf{2 0 1 2}$ & $\mathbf{2 0 1 3}$ \\
\hline ALTA & 0,75 & 0,96 & 0,97 & 0,91 & 0,97 & 0,99 & 0,98 \\
\hline ALTASET & 1,03 & 0,99 & 0,99 & 1,02 & 1,01 & 1,00 & 1,03 \\
\hline BBI_DEVEL & 0,62 & 0,92 & 0,78 & 0,85 & 0,83 & 0,82 & 0,96 \\
\hline CELPRODE & 0,98 & 0,00 & 0,00 & 1,01 & 1,02 & 0,92 & 0,99 \\
\hline DOM_DEVEL & 0,02 & 0,02 & 0,01 & 0,02 & 0,01 & 0,01 & 0,01 \\
\hline ECHO_INV & 0,57 & 0,49 & 0,60 & 0,76 & 0,74 & 0,82 & 0,85 \\
\hline ED_INVEST & 0,41 & 0,16 & 0,25 & 0,25 & 0,02 & 0,04 & 0,04 \\
\hline GTC & 0,86 & 0,97 & 0,96 & 0,94 & 0,95 & 0,96 & 1,11 \\
\hline JW_CONST & 0,40 & 0,76 & 0,66 & 0,63 & 0,67 & 0,76 & 0,80 \\
\hline KCI & 0,55 & 0,92 & 0,76 & 0,41 & 0,56 & 0,64 & 0,63 \\
\hline LCCORP & 0,90 & 0,95 & 0,86 & 0,84 & 0,82 & 0,83 & 0,98 \\
\hline POLNORD & 0,35 & 0,47 & 0,42 & 0,44 & 0,45 & 0,69 & 0,94 \\
\hline TRITON & 0,16 & 0,97 & 0,97 & 0,98 & 0,91 & 0,85 & 0,81 \\
\hline WIKANA & 0,95 & 0,40 & 0,45 & 0,55 & 0,45 & 0,66 & 0,42 \\
\hline Średnia & 0,61 & 0,64 & 0,62 & 0,69 & 0,67 & 0,72 & 0,75 \\
\hline Mediana & 0,59 & 0,84 & 0,71 & 0,80 & 0,78 & 0,82 & 0,89 \\
\hline Odchylenie standardowe & 0,317 & 0,377 & 0,347 & 0,312 & 0,338 & 0,313 & 0,355 \\
\hline Współczynnik zmienności [\%] & 192,50 & 170,40 & 178,03 & 219,75 & 198,76 & 227,57 & 210,93 \\
\hline & 0 & & & & \\
\hline
\end{tabular}

Źródło: obliczenia własne na podstawie danych Notoria - Serwis_2014.

Wyznaczone wskaźniki cechuje wysoka zmienność oraz lewostronna asymetria rozkładu w poszczególnych latach (tabela 1). Połowa badanych spółek charakteryzuje się wskaźnikiem pokrycia majątku trwałego kapitałem własnym na poziomie od 0,59 do 0,89 . Wskaźnik mniejszy od jedności w przypadku spółek deweloperskich oznacza przede wszystkim duży zasób nieruchomości, w tym również gruntowych 
pod przyszłe inwestycje. Najwyższe wartości wskaźnika notowały spółki najmniejsze, jak TRITON i ALTA, ale znalazły się również dwie, dla których wartość majątku długookresowego przekraczała kapitały długookresowe (ALTASET, CELPRODE). Dodatkowo można zauważyć, że w tych spółkach w porównaniu z innymi majątek krótkookresowy jest na niskim poziomie w stosunku do kapitałów krótkookresowych (tabela 2).

Tabela 2. Wskaźniki pokrycia majątku obrotowego kapitałem krótkookresowym wybranych spółek deweloperskich notowanych na GPW

\begin{tabular}{|c|c|c|c|c|c|c|c|}
\hline \multirow{2}{*}{ Spółka } & \multicolumn{7}{|c|}{ Majątek krótkookresowy/kapitału krótkookresowego $(>1)$} \\
\hline & 2007 & 2008 & 2009 & 2010 & 2011 & 2012 & 2013 \\
\hline ALTA & 18,43 & 10,44 & 11,86 & 14,46 & 3,3 & 4,53 & 2,23 \\
\hline ALTASET & 0,35 & 1,86 & 1,35 & 0,09 & 0,15 & 0,44 & 0,11 \\
\hline BBI_DEVEL & 35,71 & 2,13 & 4,62 & 3,45 & 3,93 & 2,86 & 1,15 \\
\hline CELPRODE & 1,24 & 26,47 & 1,13 & 0,25 & 0,30 & 3,22 & 3,09 \\
\hline DOM_DEVEL & 5,45 & 2,82 & 3,81 & 3,68 & 2,51 & 4,29 & 4,56 \\
\hline ECHO_INV & 2,42 & 3,00 & 2,81 & 1,71 & 2,01 & 1,43 & 1,48 \\
\hline ED_INVEST & 1,16 & 2,43 & 2,10 & 1,90 & 3,26 & 3,23 & 2,81 \\
\hline GTC & 52,78 & 1,48 & 7,35 & 13,01 & 2,72 & 1,33 & 0,24 \\
\hline JW_CONST & 1,87 & 1,11 & 1,18 & 1,53 & 1,72 & 1,72 & 1,72 \\
\hline $\mathrm{KCI}$ & 3,90 & 1,18 & 1,44 & 7,81 & 14,20 & 14,45 & 19,96 \\
\hline LCCORP & 1,53 & 1,54 & 4,30 & 7,86 & 6,47 & 3,93 & 1,14 \\
\hline POLNORD & 3,88 & 2,48 & 5,53 & 9,57 & 3,67 & 3,71 & 1,94 \\
\hline TRITON & 56,31 & 5,61 & 5,78 & 3,10 & 3,26 & 3,64 & 33,73 \\
\hline WIKANA & 3,83 & 90,07 & 2,88 & 2,03 & 3,00 & 1,27 & 1,75 \\
\hline Średnia & 13,49 & 10,90 & 4,01 & 5,03 & 3,61 & 3,57 & 5,42 \\
\hline Mediana & 3,86 & 2,46 & 3,35 & 3,27 & 3,13 & 3,22 & 1,85 \\
\hline Odchylenie standardowe & 19,832 & 23,752 & 2,975 & 4,693 & 3,422 & 3,383 & 9,537 \\
\hline Współczynnik zmienności [\%] & 68,02 & 45,90 & 134,83 & 107,25 & 105,44 & 105,67 & 56,84 \\
\hline
\end{tabular}

Źródło: obliczenia własne na podstawie danych Notoria - Serwis_2014.

Można również dostrzec, że w miarę pogłębiania się dekoniunktury na rynku nieruchomości obejmującej lata 2009-2013 wzrasta przeciętna wartość analizowanych wskaźników dla kapitałów długookresowych, a maleje dla kapitałów 
krótkookresowych. Cechą charakterystyczną sektora deweloperskiego jest to, że inwestycje są realizowane przede wszystkim ze środków obcych, przy czym w okresach koniunktury gospodarczej płynność inwestycji jest wysoka, więc nie zachodzi konieczność angażowania kapitałów własnych, natomiast w okresach dekoniunktury z uwagi na niską płynność inwestycji często w inwestycje zaangażowane są większe kapitały własne.

Analizując strukturę majątku ogółem, zauważono, że badane spółki różnią się znacznie strukturą majątku trwałego i majątku obrotowego. W badanych latach aktywa trwałe przeważały w spółkach: ALTA, ALTASET, BBI_DEVEL, CELPRODE, GTC, LCCORP, TRITON, WIKANA. Natomiast sytuacja przeciwna miała miejsce w takich spółkach, jak: DOM_DEVEL, ECHO_INV, ED_INVEST. Spółka JW_CONST charakteryzowała się w badanych latach przewagą majątku obrotowego na poziomie $75 \%$ w latach koniunktury, podczas gdy proporcja ta odwracała się w miarę pogłębiania się kryzysu. Podobna sytuacja miała miejsce w przypadku spółek KCI oraz POLNORD, czyli dużych spółek dobrze postrzeganych na rynku inwestycji mieszkaniowych.

W strukturze majątku trwałego badanych spółek przeważały sytuacje, w których inwestycje długoterminowe stanowiły blisko $100 \%$ tego majątku, podczas gdy rzeczowy majątek trwały nie przekraczał nawet 1\%. Wyjątkiem są spółki DOM DEVEL oraz JW_CONST, w których w latach kryzysu gospodarczego nawet ponad połowę majątku trwałego stanowił rzeczowy majątek trwały z tendencją wzrostową w miarę upływu czasu. Są to najwięksi i najdłużej działający deweloperzy na polskim rynku mieszkaniowym, w zasobach których znajdują się liczne rezerwy terenów pod kolejne inwestycje. Można również zauważyć, że spółki, które miały wysoki udział inwestycji długoterminowych w majątku trwałym, mają też wysoki (blisko 100-procentowy) udział inwestycji krótkoterminowych w majątku obrotowym, i na odwrót - wysoki udział zapasów wykazują spółki, które cechuje wysoki udział rzeczowego majątku trwałego w majątku trwałym ogółem (np. DOM_DEVEL).

Analiza kapitałów własnych oraz zobowiązań i rezerw na zobowiązania wskazuje, iż spółki mniejsze i krócej działające na rynku wykazują przede wszystkim kapitał własny w pasywach na wysokim poziomie bliskim 100\% (ALTA, ALTASET, BBI_DEVEL, CELPRODE, KCI, LCCORP, TRITON, WIKANA), podczas gdy takie spółki, jak DOM_DEVEL, ECHO_INV, JW_CONST, mają bardziej zrównoważone kapitały własne ze zobowiązaniami. Dwie spółki w badanych latach - GTC oraz POLNORD - odbiegają od tego modelu, ponieważ kapitały własne stanowią w nich około 75\% kapitałów ogółem. Niezależnie od okresu koniunktury lub dekoniunktury 
omówiona struktura kapitałów ogółem w tych spółkach zmienia się tylko nieznacznie. W spółkach o wysokim udziale kapitałów własnych w kapitałach ogółem znaczącą część stanowi kapitał zapasowy, w uzupełnieniu kapitał zakładowy. W pozostałych jest to również kapitał zapasowy, ale z kilkuprocentowym udziałem zysków lub strat z lat ubiegłych. Spółką, która generowała w analizowanych latach przede wszystkim zyski wykazane w kapitałach własnych, jest DOM_DEVEL. Najwyższy udział zysku w kapitałach własnych zanotowała ona w 2007 roku (33,6\%). W latach kryzysu udział zysku w kapitałach własnych był na poziomie 5,1-10,2\%. Była to jedyna $\mathrm{z}$ analizowanych spółek, która nie wykazała w tym okresie straty w strukturze kapitałów własnych. Dotyczy to również udziału w kapitale własnym zysków i strat z lat ubiegłych.

Analiza struktury kapitałów obcych wskazuje na podobną jak wcześniej zależność. Spółki niezbyt długo działające na rynku finansują swoje inwestycje przede wszystkim zobowiązaniami długoterminowymi stanowiącymi nawet $80 \%$ kapitałów obcych w przeciwieństwie do spółek o długiej historii rynkowej, jak te wymienione w tabeli 3, które w istotnym stopniu finansują inwestycje zobowiązaniami krótkoterminowymi przy jednoczesnej tendencji malejącej wraz z pogarszającą się sytuacją na rynku.

Tabela 3. Wskaźniki pokrycia majątku obrotowego zobowiązaniami krótkoi długoterminowymi wybranych spółek deweloperskich notowanych na GPW

\begin{tabular}{|l|c|c|c|c|c|c|c|c|}
\hline \multirow{2}{*}{ Zobowiązania } & \multicolumn{7}{|c|}{ Lata } \\
\cline { 2 - 8 } & 2007 & 2008 & 2009 & 2010 & 2011 & 2012 & 2013 \\
\hline \multicolumn{7}{|c|}{ DOM_DEVEL } \\
\hline długoterminowe & $59,57 \%$ & $42,99 \%$ & $50,32 \%$ & $48,75 \%$ & $29,58 \%$ & $45,92 \%$ & $51,08 \%$ \\
\hline krótkoterminowe & $40,43 \%$ & $57,01 \%$ & $49,68 \%$ & $51,25 \%$ & $70,42 \%$ & $19,78 \%$ & $16,73 \%$ \\
\hline \multicolumn{7}{|c|}{ ECHO } \\
\hline długoterminowe & $63,72 \%$ & $64,84 \%$ & $66,66 \%$ & $56,30 \%$ & $66,81 \%$ & $51,19 \%$ & $57,68 \%$ \\
\hline krótkoterminowe & $36,28 \%$ & $33,48 \%$ & $30,84 \%$ & $41,59 \%$ & $31,99 \%$ & $46,90 \%$ & $41,92 \%$ \\
\hline \multicolumn{7}{|c|}{ JW_CONST } \\
\hline długoterminowe & $30,64 \%$ & $12,96 \%$ & $8,95 \%$ & $33,62 \%$ & $46,09 \%$ & $15,14 \%$ & $11,52 \%$ \\
\hline krótkoterminowe & $69,36 \%$ & $87,04 \%$ & $91,05 \%$ & $66,38 \%$ & $53,91 \%$ & $39,14 \%$ & $37,58 \%$ \\
\hline
\end{tabular}

Źródło: obliczenia własne na podstawie danych Notoria - Serwis_2014. 


\section{Podsumowanie}

Analiza struktury majątku polskich firm deweloperskich notowanych na GPW i działających w sektorze inwestycji mieszkaniowych pozwala zauważyć prawidłowości specyficzne dla tego sektora, związane również z trwającą w latach badania dekoniunkturą na rynku nieruchomości. $Z$ uwagi na rodzaj aktywności można się było spodziewać dużego udziału inwestycji długoterminowych w strukturze majątku trwałego. Ma to jednak miejsce przede wszystkim w przypadku spółek mniejszych i krótko działających na rynku. W badaniu wskazano, że długotrwała aktywność i stabilność spółki deweloperskiej na rynku inwestycji mieszkaniowych skutkuje wysokim udziałem rzeczowego majątku trwałego w majątku trwałym ogółem z tendencją rosnącą w latach dekoniunktury gospodarczej. Dodatkowo okazało się, że spółki, które miały wysoki udział inwestycji długoterminowych w majątku trwałym, mają także wysoki udział inwestycji krótkoterminowych w majątku obrotowym, i na odwrót - wysoki udział zapasów wykazują spółki, które cechuje wysoki udział rzeczowego majątku trwałego w majątku trwałym ogółem. Podobnie w przypadku kapitałów własnych i obcych można dostrzec inną strategię finansową i w efekcie strukturę kapitałów spółek ustabilizowanych na rynku od lat. Spółki te sięgają też po kapitały krótkoterminowe, ale z różnym udziałem w kapitałach własnych w zależności od cyklu koniunkturalnego. Tym samym nie można potwierdzić istnienia stabilnej struktury majątku największych spółek sektora deweloperskiego i notowanych na GPW w różnych okresach koniunktury na rynku nieruchomości. Taka sytuacja powoduje, że inwestorzy giełdowi nie mają dobrego benchmarku dla oceny fundamentalnej tej części wyników ekonomiczno-finansowych spółek deweloperskich, a ich decyzje inwestycyjne musi poprzedzać analiza strategii inwestycyjnej spółki w powiązaniu z wykazywanym majątkiem.

\section{Literatura}

Batóg, J. (1996). Ocena sytuacji ekonomiczno-finansowej firmy - propozycja syntetycznej miary. Materiały Konferencyjne. Szczecin: Wyd. Naukowe US.

Batóg, J. (1997). Propozycja klasyfikacji firm według sytuacji ekonomiczno-finansowej. W: K. Jajuga, M. Walesiak (red.), Taksonomia. Klasyfikacja i analiza danych. Teoria i zastosowania (s. 68-79). T. 4. Wrocław: Wyd. UE we Wrocławiu.

Bednarski, L., Borowiecki, R., Duraj, J., Kurtys, E., Waśniewski, T., Wersty, B. (1999). Analiza ekonomiczna przedsiębiorstwa. Wrocław: Wyd. AE we Wrocławiu. 
Bednarski, L., Waśniewski, T. (1996). Analiza finansowa w zarządzaniu przedsiębiorstwem. Warszawa: FRR.

Bień, W. (1999). Zarzadzanie finansami przedsiębiorstw. Warszawa: Difin.

Dudycz, T., Skoczylas, W. (2014). Sektorowe wskaźniki finansowe. Sytuacja finansowa przedsiębiorstw według działów (branż) w 2012 r. Rachunkowość, 3, 55-80.

Foryś, I. (2011). Spoleczno-gospodarcze determinanty rozwoju rynku mieszkaniowego w Polsce. Ujęcie ilościowe. Szczecin: Wyd. Naukowe US.

Foryś, I., Tarczyński, W. (2003). Rentowność inwestycji w nieruchomości i na rynku kapitałowym. W: Rynek nieruchomości Pomorza Zachodniego - stan i perspektywy (s. 11-14). Szczecin: IADiPG.

Jachna, T., Sierpińska, M. (2009). Ocena przedsiębiorstwa wedtug standardów światowych. Warszawa: PWN.

Łuniewska, M., Tarczyński, W. (2007). Statystyczna analiza wybranych wskaźników ekonomiczno-finansowych dla spółek notowanych na Giełdzie Papierów Wartościowych w Warszawie. Zeszyty Naukowe Uniwersytetu Szczecińskiego, 450, Prace Katedry Ekonometrii i Statystyki, 17, 615-634.

Peiser, R.B., Frey, A.B. (2003). Professional Real Estate Development. Washington, D.C.: ULI The Urban Land Institute.

Peto, R. (2011). Global Property Outlook and Role of Real Estate in the European Financial Crisis. Real Estate Issues, 36, 2, 11-20.

Skoczylas, W. (red.). (2009). Wartość poznawcza analizy sprawozdań finansowych w zarządzaniu wartością przedsiębiorstwa. W: Analiza sprawozdawczości finansowej przedsiębiorstwa (s. 335-364). Warszawa: Stowarzyszenie Księgowych w Polsce.

Skoczylas, W., Waśniewski, T. (1998). Syntetyczna ocena wyników oraz sytuacji finansowej przedsiębiorstwa. Rachunkowość, 4, 199-211.

Tyran, M.R. (2005). Wskaźniki finansowe. Kraków: Oficyna Ekonomiczna.

Waśniewski, T. (1997). Analiza finansowa w przedsiębiorstwie. Warszawa: FRR.

Wędzki, D. (2009). Analiza wskaźnikowa sprawozdania finansowego. T. 2. Kraków: Wolters Kluwer.

Zaleska, M. (2002). Ocena ekonomiczno-finansowa przedsiębiorstwa przez analityka bankowego. Warszawa: Oficyna Wydawnicza. 


\title{
THE STABILITY OF THE SELECTED INDICATORS OF ASSETS STRUCTURE DEVELOPMENT COMPANIES LISTED ON THE WARSAW STOCS EXCHANGE (WSE) IN 2007-2013
}

\begin{abstract}
The real estate market is one of the many areas of economic activity entities that suffered a crisis of recent years. Also the developers companies listing on the Warsaw Stock Exchange confirm the negative economic phenomena taking place in this sector. In the article, there is discussion of the condition of the real estate companies listed on the Warsaw Stock Exchange in the period 2007-2013 in the context of the structure of assets. The aim of the study is to assess the structure and stability of assets development companies actives in the market for housing investment in Poland. Were used the data of financial and economic indexes for investigated companies. They were the basic economic indicators - financial statements, which were used for to assess their stability in the boom years and the downturn in the real estate market.
\end{abstract}

Translated by Iwona Foryś

Keywords: development companies, indicators of asset structure, stability, structure

JEL Codes: G2, E22, R3 
